\title{
The Analysis of Effects of Operating Leverage, Financial Leverage, and Liquidity on Profitability in the Telecommunications Industry Listed in Indonesia Stock Exchange
}

\author{
Lokita Rizky Megawati \\ School of Business \\ IPB University \\ Bogor, Indonesia \\ lokita.rizky@apps.ipb.ac.id
}

\begin{abstract}
The creativity and innovation of domestic telecommunications operators is still very slow and lagging behind the creativity and innovation developed abroad. This has an impact on profitability measured by ROA on five telecommunications companies listed in the IDX. Often companies need additional funds in expanding their business units. Therefore, one of the ways in which companies fulfill their funding needs is to use operating leverage and financial leverage. In this case the company must also pay attention to company liquidity, which is the company's ability to pay all short-term financial obligations at maturity. The purpose of this study is to analyze the effect of operating leverage (DOL), financial leverage (DFL) and liquidity (CR) on profitability (ROA) in the telecommunications industry listed in the IDX. The research method used is descriptive verification analysis with explanatory survey approach and hypothesis testing using multiple regression analysis with panel data. The sampling technique uses purposive sampling to obtain five companies of research samples. Research period for 20122018. The results of this study are operating leverage and financial leverage not significant positive effect on profitability, liquidity has a significant negative effect on profitability, and simultaneously operating leverage, financial leverage, and liquidity have an effect on profitability. Suggestions that can be given in accordance with the results of the study are for Telecommunications Companies need to perform liquidity risk management which means maintaining sufficient cash balances in the effort to fulfill financial liabilities.
\end{abstract}

Keywords: financial leverage, liquidity, operating leverage, profitability, telecommunication company

\section{INTRODUCTION}

The rapid growth of the telecommunications industry has a tremendous impact on the growth of the Indonesian economy because the telecommunications industry has become a driving force for the entire sector, starting from the telecommunications industry itself to encouraging other sectors such as the trade, manufacturing and small and medium business sectors to drive the people's economy. The use of metamorphosed cellular services looks for forms and experiences a shift along with technological developments. The era of telecommunications in Indonesia is now entering a period of degradation. Where the creativity and innovation of our telecommunications operators are still very slow and lagging behind what is offered outside. So that some companies have started to get distracted and entered in red ocean conditions. Acquisitions and mergers in several telecommunications companies began to appear.

The purpose of the company is to be able to maximize the value of the company or shareholders' wealth and maximize profits. The company in its business activities always strives to achieve optimal profits and with this, the company can maintain its survival. For companies, in general, the problem of profitability is more important than the problem of profit, because even large profits are not a measure that the company has been able to work efficiently. The new efficiency can be known by comparing the profits, or in other words calculating the level of profitability.

For more details about profitability, provides an understanding that the profitability of companies shows the comparison between profits with assets or capital that generates profits [1]. While the others argues that profitability or also called profitability illustrates the ability of companies to make profits through all capabilities, and existing sources such as sales, cash, capital, number of employees, number of branches and so on [2]. And the use of profitability is to measure how much profit can be obtained by the company [3]. From the three definitions, it can be concluded that profitability is the achievement achieved by the company in a certain period that is obtained by using all the capabilities of either the company's capital or assets.

Every company needs funds to support the company's activities. Funds can be obtained from internal companies or from outside parties. But in managing company business units, companies often need additional funds to expand their business units. Therefore, one of the ways in which a company fulfills funding needs is financial leverage and operating leverage. Operating leverage relates to the relationship between sales results and the level of income before interest and tax payments (the firm's sales revenue to its earnings before interest and taxes). Operating leverage arises because of the fixed operating costs used in the company to generate income. Fixed operating costs do not change with changes in sales volume. Operating leverage measures changes in income or sales to operating profits. 
Financial leverage is the second step in the process of increasing profits. In the first step operating profit enlarges the effect of sales changes on changes in operating income. In the second step, the financial manager has the choice to use the Financial leverage lever to increase the effect of each change in operating income on changes in earnings per share (EPS).

In this case, also the company must pay attention to company liquidity. Liquidity is an indicator of a company's ability to pay all short-term financial obligations at maturity using available current assets [4]. In addition, liquidity is showing the ability of a company to fulfill its financial obligations that must be fulfilled immediately, or the company's ability to meet financial obligations at the time of collection [5].

The success and bankruptcy of the company become the duties and responsibilities of the company management depending on the policies that have been taken by the company management. Including decisions regarding financial policy to support every activity of the company in an effort to achieve its objectives, namely to maintain a stable level of profitability and analyze the factors that cause the level of profitability to decline in this last period. Based on the background stated above, researchers are interested in conducting research with the title "Analysis of the Effects of Operating Leverage, Financial Leverage, and Liquidity on Profitability in the Telecommunications Industry Registered on the IDX

\section{MATERIALS AND METHODS}

According to Gitman [6] there are several ways to measure the profitability of a company, namely Gross Profit Margin, Operating Profit Margin, Net Profit Margin, Earning Per Share, Return on Assets (ROA) and Return on Equity (ROE). This study is limited to only using the Return on Assets (ROA) ratio. ROA measures the profitability of a company. Return on Assets is a measure of the effectiveness of management in generating profits with available assets. The higher the rate of return produced, the better the company will be.

According to Brigham and Houston [2] Operating leverage is how much fixed costs are used in operating a company. Irawati [7] states that operating leverage is the use of assets with fixed costs that aim to generate enough revenue to cover fixed and variable costs and can increase profitability. According to Keown, et al. [8] operating leverage is the ability of a company's EBIT to respond to sales fluctuations. The size of the operating leverage is calculated by DOL (Degree of operating leverage).

Financial leverage is the use of funds in the form of long-term debt in the company's capital structure accompanied by the obligation to pay fixed costs in the form of loan interest in the hope of increasing company profitability, because in issuing funds for fixed cost needs the company can use assets, so the company can generate income sufficient. According to Keown, et al.[8] Financial Leverage is the practice of funding some of the assets of companies with securities that bear the burden of fixed returns in the hope of increasing final returns for shareholders. The size of the financial leverage is calculated by DFL (Degree of financial leverage), which is a comparison between the percentage change in EPS with the percentage change in EBIT.

According to research conducted by Faizal Taufik Ibrahim [9], a company that has a high level of liquidity causes the company's profitability to be low. High liquidity reflects that the company's current debt is high. Companies with high liquidity mean the company prefers funding from debt. Companies that make funding come from debt, causing company profits to decrease because the company must pay the debt along with a fixed cost of interest. Liquidity is an indicator of a company's ability to pay all short-term financial obligations at maturity using available current assets [10]. From the many formulas above in this study the formula to be used is the Current Ratio formula. Current ratio is easily calculated. Besides that, the current ratio has a good bankruptcy prediction ability [8].

The study used a quantitative methodology by a descriptive verification method with an explanatory survey approach. Hypothesis testing in this study uses regression analysis with panel data that combines time series data and cross section data. Table 1 shows the definition of the operationalization variables.

TABLE 1 DEFINITION OF OPERATIONALIZATION VARIABLE

\begin{tabular}{|c|c|c|c|}
\hline Variable & $\begin{array}{c}\text { Definition of } \\
\text { Variable }\end{array}$ & Scale & Measurement \\
\hline $\begin{array}{c}\text { Return On } \\
\text { Asset }(\mathrm{Y})\end{array}$ & $\begin{array}{c}\text { ROA is the ratio } \\
\text { between earning } \\
\text { after tax to total } \\
\text { assets. }\end{array}$ & Rasio & ROA $=\frac{\text { Earning After } \text { Tax }}{\text { Total Asset }} \times 100 \%$ \\
\hline $\begin{array}{c}\text { Degree of } \\
\text { Operating } \\
\text { Leverage } \\
\left(\mathrm{X}_{1}\right)\end{array}$ & $\begin{array}{c}\text { measure the effect } \\
\text { of changes in sales } \\
\text { volume to the } \\
\text { change in EBIT }\end{array}$ & Rasio & DOL $=\frac{\text { Percentage change in EBIT }}{\text { Percentage change in sales }}$ \\
\hline $\begin{array}{c}\text { Degree of } \\
\text { Financial } \\
\text { Leverage } \\
\left(\mathrm{X}_{2}\right)\end{array}$ & $\begin{array}{c}\text { measure the effects } \\
\text { of changes in EBIT } \\
\text { to changes in } \\
\text { earnings per share } \\
\text { for the company }\end{array}$ & Rasio & DFL $=\frac{\text { Percentage change in EPS }}{\text { Percentage change in EBIT }}$ \\
\hline $\begin{array}{c}\text { Current } \\
\text { Ratio }\left(\mathrm{X}_{3}\right)\end{array}$ & $\begin{array}{c}\text { comparing the } \\
\text { current assets by } \\
\text { current liabilities }\end{array}$ & Rasio & Current Ratio = Current assets \\
\hline
\end{tabular}

Sources : Riyanto (2011), Brigham (2010), Gitman (2012)

The population in this study were all Telecommunications Industries listed on the Indonesia Stock Exchange (IDX), which were 11 companies. Company samples used in this study (Table 2) were selected by purposive sampling. The considerations are: (1) Companies in the telecommunications subsector that are listed on the Indonesia Stock Exchange (IDX). (2) Issued complete financial statements from 2012 to 2018.

TABLE 2 SAMPLES TELECOMMUNICATIONS INDUSTRY LISTED IN BEI (DATA AS OF DECEMBER 2018)

\begin{tabular}{|c|c|}
\hline Companies's Name & Code Share \\
\hline Bakrie Telecom & BTEL \\
\hline XL Axiata & EXCL \\
\hline Smartfren Telecom & FREN \\
\hline Indosat & ISAT \\
\hline Telekomunikasi Indonesia & TLKM \\
\hline Total & 5 Companies \\
\hline
\end{tabular}

Souruce : www.idx.co.id (processed)

The regression equation as follows: Where :

$$
\mathrm{ROA}_{i t}=\boldsymbol{\beta}_{0}+\boldsymbol{\beta}_{1} D O L_{i t}+\boldsymbol{\beta}_{2} D F L_{i t}+\boldsymbol{\beta}_{3} C R_{i t}+u_{\mathrm{it}}
$$

$\beta_{0}=$ Constanta 
$\beta_{1} \ldots . . . \beta_{3}=$ Regression Coefficients

$\mathrm{i}=$ cross section

$\mathrm{t}=$ time series

e $=$ errorterm

Based on the regression models and the determined variables, the test hypothesis are as follows:

1. Effect of Operating Leverage (DOL) on Return on Asset (ROA) companies

$\mathrm{H}_{0}$ : There is no positive effect of Operating Leverage (DOL) on Return on Asset (ROA) Companies $(\beta 1 \leq 0)$

$\mathrm{H}_{1}$ : There is a positive influence between Operating Leverage (DOL) on Return on Asset (ROA) Companies $(\beta 1>0)$

2. Effect of Financial Leverage (DFL) on Return on Asset (ROA) companies

$\mathrm{H}_{0}$ : There is no positive effect of Financial Leverage (DFL) on Return on Asset (ROA) Companies ( $\beta 2 \leq 0)$

$\mathrm{H}_{1}$ : There is a positive influence between Financial Leverage (DFL) on Return on Asset (ROA) Companies $(\beta 2>0)$

3. Effect of Liquidity (Current Ratio) to Return on Assets (ROA) companies

$\mathrm{H}_{0}$ : There is no negative effect of Liquidity (Current Ratio) to Return on Assets (ROA) of companies ( $\beta 3 \geq 0$ ) $\mathrm{H}_{1}$ : There is a negative influence between Liquidity (Current Ratio) to Return on Assets (ROA) of companies $(\beta 3<0)$

\section{RESULTS}

This study uses five telecommunications companies listed on the Indonesia Stock Exchange as research samples. The sample selection was carried out using purposive sampling technique, where from the predetermined criteria selected as many as 5 companies with 35 samples of research observations. The data used in this study were taken from www.idx.co.id and www.bi.go.id so that researchers get data on the company's financial statements for the period of the research year, namely 2012-2018. So that it can be calculated the financial ratios used in research including operating leverage (DOL), financial leverage (DFL), liquidity (CR), and profitability (ROA). Fig.1, Fig. 2, Fig. 3, and Fig. 4 shows the corresponding financial statements.

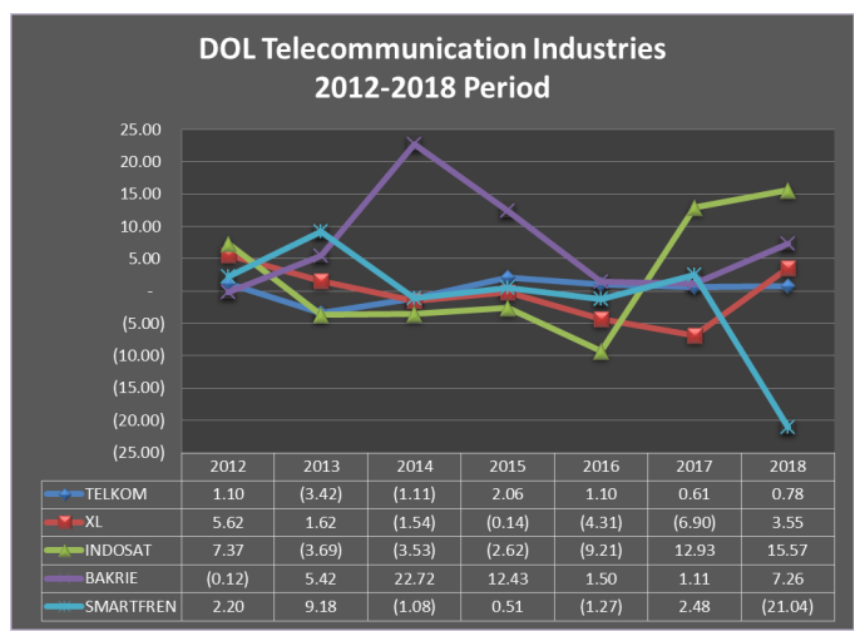

Fig. 1 DOL Telecommunication Industries 2012-2018 Period

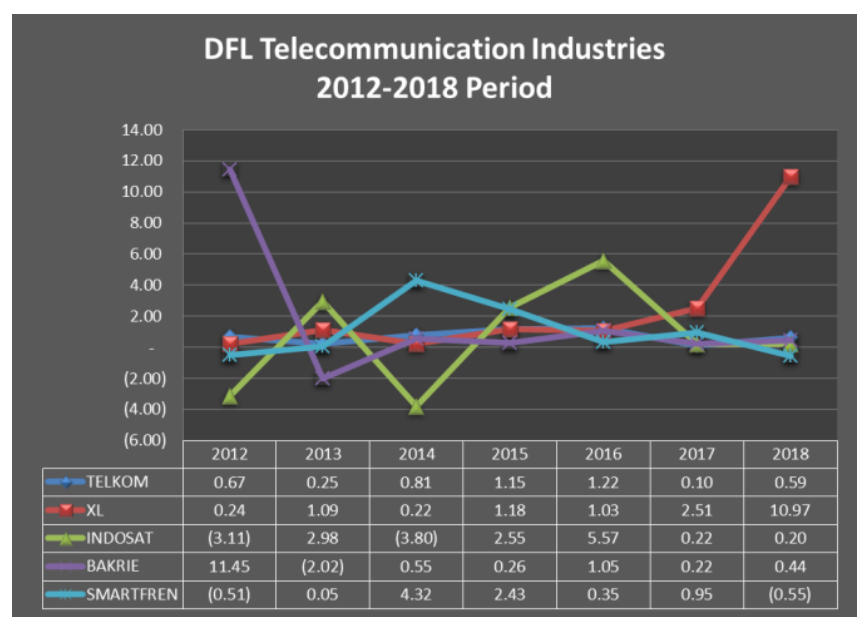

Fig. 2 DFL Telecommunication Industries 2012-2018 Period

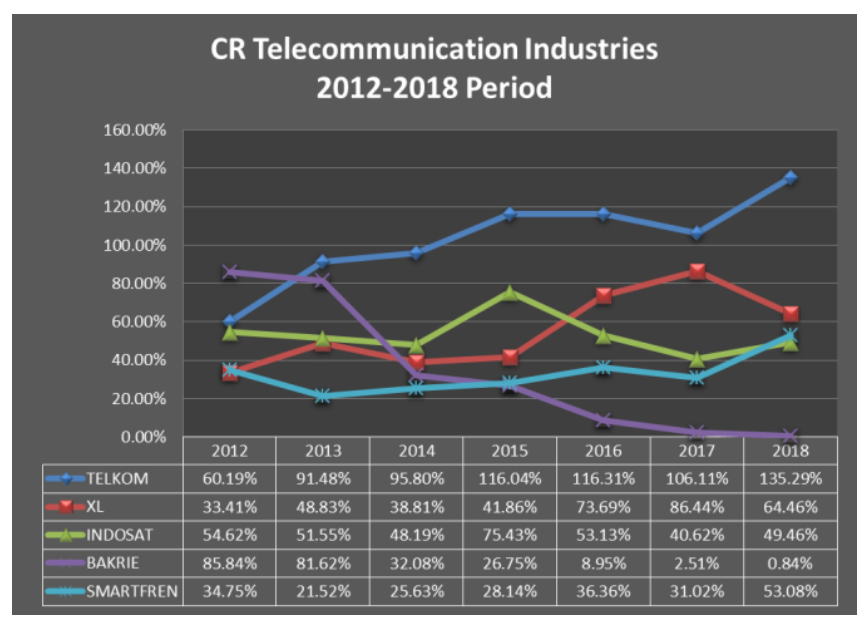

Fig. 3 CR Telecommunication Industries 2012-2018 Period

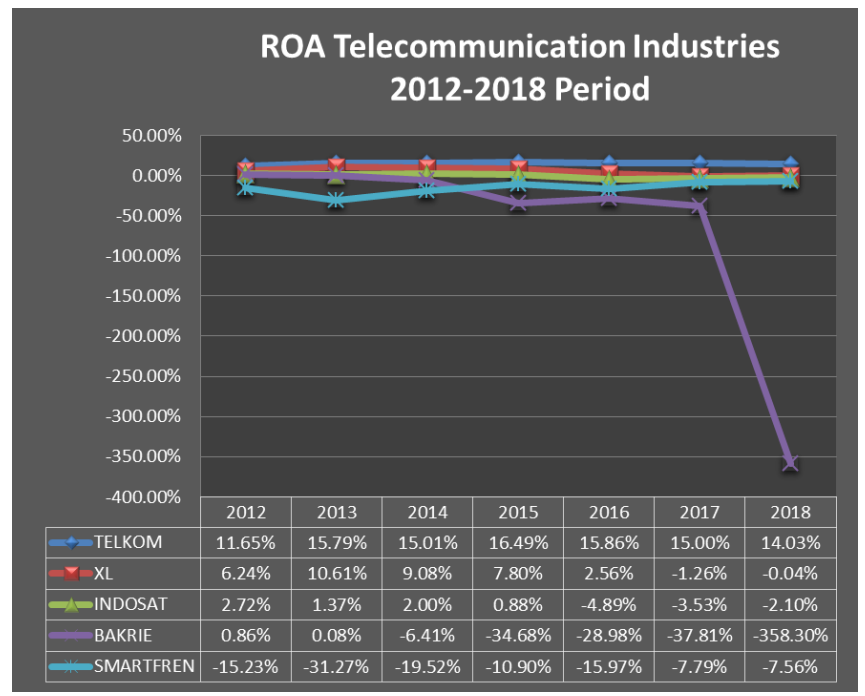

Fig. 4 ROA Telecommunication Industries 2012-2018 Period 


\section{A. Test Results Statistics}

\section{Panel Data Regression}

Based on model testing that has been done by using Chow test and Hausman test in this study, the selected Fixed Effect Model with the following equation: Profitability $(\mathrm{ROA})=-0,626611+0,002787 \mathrm{DOL}+$ 0,019637 DFL $-0,856470 \mathrm{CR}+\varepsilon$

From the multiple regression models above it can be explained, that:

1. The value of $\mathrm{C}$ or constant indicates the number $-0,626611$ means profitability (ROA) of $-0,626611$ when operating leverage (DOL), financial leverage (DFL), Liquidity (CR), and $\varepsilon$ is equal to zero.

2. The coefficient of operating leverage (DOL) shows the number 0,002787 . This means that operating leverage (DOL) has a positive effect on profitability (ROA), if there is an increase operating leverage (DOL) one unit of profitability (ROA) increased by 0,002787 units.

3. The coefficient of financial leverage (DFL) indicates the number 0,019637. This means that financial leverage (DFL) has a positive effect on profitability ( $\mathrm{ROA})$, if there is an increase in financial leverage (DFL) one unit of profitability (ROA) increased by 0,019637 units.

4. The coefficient of liquidity (CR) indicates the number $-0,856470$. This means that liquidity (CR) has a negative effect on profitability (ROA), if there is an increase of liquidity (CR) of the unit profitability (ROA) decreased - 0,856470 unit.

\section{Classical Assumption Test}

Based on the calculation of autocorrelation in this study it was found that the value of the Durbin-Watson statistic in other words 1,100 or approaching 2 the residual value has no autocorrelation.

Based on the calculation multicolinearity test result that variable DOL, DFL, and CR have a tolerance value of more than 0.1 and VIF is not more than 5 , it can be concluded that in this study did not happen multicollinearity between independent variables.

Based on the data that has been processed, the data does not describe a systematic pattern that does not indicate there is heteroscedasticity in the data in this study.

\section{B. Hypothesis Testing Results}

1. Results of Testing Hypotheses with the Statistical t Test From the random effect regression model, the $t_{\text {test }}$ is obtained as follows:

TABLE 3 FIXED EFFECT REGRESSION MODEL RESULTS

\begin{tabular}{crrrr}
\hline \hline Variable & Coefficient & Std. Error & t-Statistic & Prob. \\
\hline \hline ROA & -0.626611 & 0.311225 & -2.013369 & 0.0528 \\
DOL & 0.002787 & 0.043315 & 0.064343 & 0.6491 \\
DFL & 0.019637 & 0.166049 & 0.118260 & 0.6066 \\
CR & -0.856470 & 0.305600 & -2.802586 & 0.0087 \\
\hline \hline
\end{tabular}

Source : Eviews9 (data processed)
From the results of the calculation of the random effect regression model, it is obtained the value of each independent variable that will be tested by using $t_{\text {test }}(t-$ statistic) as well as the $t_{\text {table }}$ for $\alpha=0,05$ with degrees of freedom $(\mathrm{df}=\mathrm{n}-2) 33$ obtained $\mathrm{t}_{\text {table }}=1,69236$

\section{Effect of Operating Leverage on Profitability}

Based on panel data regression analysis calculations obtained: significance value $0,6491>0,05$. Then, with a $95 \%$ confidence level that the operating leverage (DOL) is not significant positive effect on profitability (ROA) in the telecommunications company listed in Indonesia Stock Exchange in 2012-2018.

\section{Effect of Financial Leverage on Profitability}

Based on panel data regression analysis calculations obtained: significance value $0,6066>0,05$. Then, with a $95 \%$ confidence level that the financial leverage (DFL) is not significant positive effect on profitability (ROA) in the telecommunications company listed in Indonesia Stock Exchange in 2012-2018.

\section{Effect of Liquidity on Profitability}

Based on panel data regression analysis calculations obtained: significance value $0,0087<0,05$. Then, with a 95\% confidence level that the liquidity (CR) have a significant negative effect on profitability (ROA) in the telecommunications company listed in Indonesia Stock Exchange in 2012-2018.

\section{Determination Coefficient Test Results and Statistical F Tests}

Table 4 shows the determination coefficient results and the test $\mathrm{F}$ statistics. Based on the results of calculations using the random effects regression model equation in table 3.2 obtained Adjusted R-squared $=0.481094$, meaning that the effect of all independent variables simultaneously on the dependent variable is $48.1094 \%$ and the rest is influenced by other factors not included in the research model.

TABLE 4 DETERMINATION COEFFICIENT RESUltS TABLE AND TEST F STATISTICS

\begin{tabular}{cc}
\hline \hline R-squared & 0.549693 \\
Adjusted R-squared & 0.481094 \\
S.E. of regression & 0.060430 \\
Sum squared resid & 0.480200 \\
Log likelihood & 24.85460 \\
F-statistic & 12.07418 \\
Prob(F-statistic) & 0.001700 \\
\hline \hline
\end{tabular}

Source : Eviews9 (data processed)

The F-statistic value in Table 3.2 is 12.07418 and the Fstatistic probability is 0.001700 . So from the results of simultaneous testing the F-statistic probability (0.001700) 
$<\alpha(0.05)$, which means the operating leverage, financial leverage, and liquidity variables simultaneously have a significant effect on the profitability variable.

\section{DISCUSSION}

The success and bankruptcy of telecommunications companies become the duties and responsibilities of the company's management, which depends on the policies that have been taken by the management of the company to support every activity of the company in an effort to achieve the goal of maintaining a stable level of profitability. Investors need to pay attention to the effectiveness of the company in managing its assets in generating profits. The results of this study are expected to provide useful information for investors in making the right decisions regarding their investments by taking into account financial ratios measured by ROA, DOL, DFL, and Current Ratio.

\section{A. The Effect of Operating Leverage on Profitability}

Based on data analysis and hypothesis testing conducted in this study, it can be seen that the operating leverage factor projected with DOL has no significant positive effect on profitability that is projected by ROA. A positive relationship between DOL and ROA means that an increase in operating leverage will be followed by an increase in company profitability.

This study has the same results with the research conducted [14], the size of profitability is influenced by fixed costs borne by the company. Operating leverage occurs every time the company has operating costs that must be closed, regardless of the units produced. The level of operating leverage of a company at an output level indicates the percentage change in profits due to changes in output that cause changes in earnings. But the magnitude of changes in sales is not comparable to changes in operating profits obtained by the company. Resulting in an insignificant positive effect between operating leverage on profitability.

\section{B. The Effect of Financial Leverage on Profitability}

Based on data analysis and hypothesis testing conducted in this study, it can be seen that the financial leverage factor projected by DFL has a significant positive effect on profitability that is projected with ROA. A positive relationship between DFL and ROA means that an increase in financial leverage will be followed by an increase in company profitability.

This study has the same results with the research conducted [11], DFL which is the result of the calculation of financial leverage analysis has a high leverage to generate high profitability as well. And if profitability rises, it shows the ability of the capital invested in overall assets to generate profits for shareholders. Vice versa, if DFL decreases the leverage to generate ROA will also decrease. This means that profits available to shareholders have decreased. If ROA increases, in addition to increasing the welfare of shareholders, it will also create high confidence in the company's success in managing the company and can also attract new investors to invest in the company.

\section{The Effect of Liquidity on Profitability}

Based on data analysis and hypothesis testing conducted in this study, it can be seen that the liquidity factor that is projected by $\mathrm{CR}$ has no significant negative effect on profitability that is projected by ROA. The negative relationship between $\mathrm{CR}$ and ROA means that the decrease in liquidity will be followed by an increase in the company's profitability.

This research has the same results as the research conducted by Faizal Taufik Ibrahim [9], a company that has a high level of liquidity causes the company's profitability to be low. High liquidity reflects that the company's current debt is high. Companies with high liquidity mean the company prefers funding from debt. Companies that make funding come from debt, causing company profits to decrease because the company must pay the debt along with a fixed expense, namely the interest expense.

To face increasingly fierce telecommunications competition, companies invest more in fixed assets. As a result this will reduce the level of profitability of the company, because fixed assets will produce results that require a long time or not a moment. This is that high liquidity is not always profitable because it has the opportunity to generate funds that are unemployed which can actually be used to invest in projects that benefit the company.

\section{CONCLUSION}

Operating leverage, financial leverage, and liquidity simultaneously affect the profitability of telecommunications companies listed on the Indonesia Stock Exchange in the 2012-2018 period. Operating leverage (DOL) does not have a significant positive effect on profitability (ROA) which explains that every increase in operating leverage (DOL) will increase profitability (ROA). Financial leverage (DFL) has not a significant positive effect on profitability (ROA) which explains that every increase in financial leverage (DFL) will increase profitability (ROA). Liquidity (CR) has a significant negative effect on profitability (ROA) which explains that any increase in liquidity $(\mathrm{CR})$ will reduce profitability (ROA).

The concept of operating and financial leverage is useful for financial analysis, planning and control. However, operating and financial leverage are proven to have no significant effect on the profitability of telecommunications companies, so that the size of the profitability received by telecommunications companies is not influenced by business risk and financial risk.

In addition, the management must maintain the company's liquidity needs, because it has been proven that liquidity has a significant effect on company profitability. The value of liquidity that is too high has an unfavorable 
impact on earning power because of the presence of iddle cash or shows the excess working capital needed, this excess will reduce the opportunity for profit.

\section{REFERENCES}

[1] Riyanto, B. “Dasar-dasar Pembelanjaan Perusahaan”. Yogyakarta: BPFE, 2011.

[2] Harahap, Sofyan S. “Analisis Kritis atas Laporan Keuangan”. Jakarta: PT. Raja Grafindo Persada, 2010.1

[3] Sutrisno. "Manajemen Keuangan". Yogyakarta: Ekonesia, 2009.

[4] Syamsuddin, L. “Manajemen Keuangan Perusahaan.”. Jakarta: PT. Raja Grafindo Persada, 2009.

[5] Munawir, S. “Analisa Laporan Keuangan”. Yogyakarta: Liberty, 2010.

[6] Gitman, Lawrence J. \& Chad J. Zutter. "Principles of Managerial Finance. 13th Edition". Pearson International Edition. Global Edition, 2012.

[7] Irawati, S. "Manajemen Keuangan". Bandung: Penerbit Pustaka, 2007.

[8] Arthur J. Keown, David F. Scott, Jr., John D. Martin, J. William Petty. "Manajemen Keuangan: Prinsip dan Penerapan Jilid 1 (Edisi Kesepuluh”). Jakarta: PT. Indeks, 2010.

[9] Faizal Taufik Ibrahim. "Analisis Pengaruh Leverage, Likuiditas, Perputaran Modal Kerja, Dan Pertumbuhan Penjualan Terhadap Profitabilitas Perusahaan (Studi pada Perusahaan Manufaktur Sektor Industri Barang Konsumsi yang Terdaftar di BEI pada Tahun 2009-2013)”. Semarang: Universitas Diponegoro, 2015.

[10] Waqas Bin Khidmat and Mobeen Ur Rehman. "Impact of Liquidity \& Solvency on Profitability Chemical Sector of Pakistan”. Pakistan: GC University, Faisalabad, 2014.

[11] Indo Ratmana Putra. "Analisis Pengaruh Operating Leverage dan Financial Leverage Terhadap Earning Per Share (EPS) di Perusahaan Properti yang Terdaftar di BEI (2007-2011)”. Surabaya: Universitas Negeri Surabaya, 2013. 